\title{
LEVERAGE INDUCED FINANCIAL DISTRESS OF MANUFACTURING FIRMS IN BANGLADESH: A COMPARISON BETWEEN LISTED MNCS AND DOMESTIC FIRMS BY APPLYING ALTMAN'S Z SCORE MODEL
}

\author{
Dr. Syed Mohammad Khaled Rahman \\ Associate Professor \\ Department of Business Administration \\ Shahjalal University of Science \& Technology, Sylhet-3114, Bangladesh \\ E-mail:kr15sust@gmail.com \\ Dr. Md. Khairul Islam \\ Professor \\ Department of Business Administration \\ Shahjalal University of Science \& Technology, Sylhet-3114, Bangladesh \\ E-mail:khairuldba@gmail.com \\ Md. Mofazzal Hossain \\ Undergraduate Student of $4^{\text {th }}$ Year $2^{\text {nd }}$ Semester \\ Department of Business Administration \\ Shahjalal University of Science and Technology, Sylhet, Bangladesh \\ E-mail: hossaintipusust@gmail.com
}

\begin{abstract}
Financial distress arises from excessive debt capital. The aim of the study was to determine Altman's Z score and show a comparative analysis of the effect of debt on Z scores of listed MNCs \& domestic firms of Bangladesh over a 24-year period (1996-2019). The study was based on secondary data. Seven domestic firms and seven MNCs were selected as sample from six manufacturing industrial sectors. It was found that on an average one local firm was in grey zone and the rest 13 firms were in safe zone ( $Z$ scores $>2.99)$. Z scores for MNCs were substantially higher than for domestic firms. The Z score's mean for MNCs was 5.398 compared to 4.155 for domestic firms. For domestic businesses, the Z score shifts by 0.001 or $0.24 \%$ for a $1 \%$ change in the opposite direction of the overall debt. For a $1 \%$ rise in overall debt, the $Z$ score of MNCs decreases by 0.005 or $0.073 \%$. Domestic companies should increase Z score by redesigning the capital structure and improving basic earning power. The study has practical implications for corporate managers, policymakers, investors, and government because future strategy, policy, and business performance depends on the zone in which the firms are situated.
\end{abstract}

Keywords: Z Score, Financial, Distress, Debt, Zone.

JEL Classification Codes: G30, G32, G39. 


\section{INTRODUCTION}

Financial distress is such a situation of a firm in which the financial obligations are met with difficulty. According to static capital structuretheory, a firm can borrow up to that level at which marginal benefit of tax shield equals the marginal cost of financial distress (Ross, Westerfield, \& Jordan 2002). There is a limit to the use of debt and after the optimum debt level cost of financial distress out weight tax shield benefit of leverage. The extreme consequence of financial distress is bankruptcy. Altman (1983) developed a model to predict bankruptcy and financial distress of firms. Using Altman's Z score model to know financial distress or bankruptcy probability has many implications to lenders, investors, regulatory authorities, government, auditors, and managers.

Several previous research works on the capital structure of Bangladeshi manufacturing companies revealed that leverage ratios are relatively high and these ratios have an adverse impact on financial performance. Ali, Rahman, \& Mahmud (2016) found that 50\% of Bangladeshi textile companies were in the 'distress' zone. Jahur and Quadir (2012) have identified fund management drawbacks and poor profitability as some of the causes of financial distress of SMEs in Bangladesh. The magnitude of debt capital directly affects the fourth component and indirectly affects other components of the $\mathrm{Z}$ score model. So, further investigation is required to estimate the $\mathrm{Z}$ score to identify in which zones the firms are situated'safe', 'grey', or 'distress' as well as how Z score changes for a particular change in debt capital.

Multi-National Companies (MNCs) operating in Bangladesh is performing satisfactorily. Compared to the year 2018, earnings of most listed MNCs have increased in 2019. Earnings per share of five MNCs have increased from the previous year. Only eleven listed MNCs account for $24 \%$ of market capitalization in Dhaka Stock Exchange (Barman, 2020). MNCs' profitability in 2018 was also higher than the previous year (The New Age, 18/5/2019). From observing the financial performances of both types of companies, it can be inferred that MNCs are more financially sound than domestic companies. But the question is -'how far local firms are lagging behind in financial soundness than MNCs?' or 'are financial distress level of local companies are significantly higher than MNCs?' The present study attempts to seek an answer to this question.

\section{PROBLEM STATEMENT}

Financial distress has many adverse effects on a firm. Bankruptcy cost reduces a firm's ability to use the borrowed fund for productive purposes. The probability that firms would be unable to provide their promised return to bondholders increases due to an increase in leverage ratios. Failure of repayment of borrowed capital to bondholders would result in the transfer of corporate assets' ownership from shareholders to bondholders. Theoretically, in a bankruptcy situation, the value of an asset becomes equal to the value of the liability, and the value of equity becomes 0 . Eventually, control of the firm goes to bondholders. Besides shareholders, creditors are also affected because their payoff reduces due to the incurrence of bankruptcy cost. They do not get the amount that the firm owes to them (Ross et al., 2002). Global financing option reduces due to COVID 19 which was revealed from the study of Afrina, Beg, Zayed, Hossain, and Shahi (2020).

There is both direct and indirect cost of financial distress. Legal and administrative costs are the direct cost of financial distress and these are incurred for legal proceedings, auditing, and accounting activities, liquidation process etc. There are many indirect costs which are very difficult to measure. Distress impairs the ability of a firm to conduct normal business operation. Suppliers deny delivering materials on favorable credit terms. Customers switch to competitor 
companies for purchasing their products. Sales decline and thus distressed firm losses its market share. Conflict between shareholders and bondholders rises for gaining corporate control. Top management body of the financially distressed firm spend their invaluable time to avoid bankruptcy rather than on core business activities which brings more trouble to the firm. Experienced and skilled employees switch to peer companies. Moreover, many productive programs and attractive projects are not undertaken due to shortage of cash. When the signal of distress is revealed then creditors raise their required rate of return which increases firm's cost of capital. The incremental requirement is considered as compensation. Increase of bondholders' fixed payoff reduces residual payoff of shareholders. Less cash flow to shareholders leads to decline in market value of shares (Brealey \& Myers, 1996). Janardhanan and Uma (2020) in their study revealed that use of debt capital significantly influences shareholders' return of financial institution. Akani and Ifechi (2017) in their research on 40 listed firms of Nigeria found that excessive debt reduced ROA and ROE significantly. From the present study it was found that local firms were more financially distressed and $\mathrm{Z}$ scores were more sensitive to change in debt than MNCs. The rest of the paper contain relevant literature in section 3, objectives, followed by hypothesis developmentin section 4 . In section 5 methodology of the study were explained and in next section findings of the study were discussed through data analysis. In section 7 concluding remarks were made along with policy implications.

\section{LITERATURE REVIEW}

Altman's Z-Score model is used to measure thefinancial distress of a company. Ross, Westerfield, and Jaffe (2005) defined financial distress as a situation where the firm's operating cash flows are not sufficient to meet the short-term commitments. Sajjan (2016) conducted research to predict the probability of bankruptcy of both manufacturing \& service-oriented firms listed in Indian stock exchanges during 2011-2015. The study revealed that the majority of firms were financially distressed which may fall in bankruptcy situation in coming years. Pradhan (2014) in her study determined Z scores of three Indian commercial banks over the periods 20012008 and by using these values and neural network, $\mathrm{Z}$ scores of future years were determined. Study found that in every year the scores were above 6 and every observation was in safe zone. Aasen (2011) in his thesis applied Altman's Z-score model to estimate the financial distress of 180 listed Norwegian firms. Study found that Z-score of manufacturing firms were less than nonmanufacturing firms. Financial distress was positively related with the issuance of equity. After summarizing the research works of Altman, Anjum (2012) concluded that distress could be successfully forecasted by using Z score model prior to 3 years. Khaddafi, Falahuddin, Heikal, \& Nandari (2017) in their study have analyzed the Z score of 29 banks of Indonesia during 20112013 and revealed that majority of the banks were financially distressed in every year and 'safe zone' banks were moving to 'distress zone'.

Johur and Quadir (2012) in their study investigated the cause and remedial measures of financial distress of SMEs in Bangladesh. They found that financial distress has adverse impact on sales, managerial capability, financial planning etc. The reasons for financial distress were poor fund management, poor financial control, poor profitability etc. Ali et al. (2016) estimated the financial soundness of 18 textile firms in Bangladesh using Altman's Z score model. From the study it was revealed that $28 \%$ of the companies fall in safe zone, $22 \%$ fall in grey zone and $50 \%$ fall in distress zone. Mizan and Hossain (2014) in their research measured the financial distress of cement industry of Bangladesh. Study found that among 5 companies, two were in safe zone and three were in distress zone. Mizan, Amin, \& Rahman (2011) in their study aimed 
to reveal the financial distress of listed pharmaceutical companies of Bangladesh. Study revealed that among 6 companies, two were in safe zone and have no bankruptcy probability. But other 4 companies were most likely to fall in financial distress within few years. Gopalakrishnan, Gupta, Raja, Reddy, \& Subbarao (2019) have undertaken a research work to assess the financial soundness of 10 Indian steel companies during 2014-2018. Study found that decrease of working capital was the main reason for financial instability. Out of 10 companies, two large and old steel companies were in distress zone and two small sized companies were in safe zone. Iheduru and Okoro (2018) investigated the determinants of retained earnings of listed manufacturing firms in Nigeria. Study found that oil price positively affects but exchange rate and interest rate adversely affect retention ratio of manufacturing firms.

Hillary, Nyang'au, \& Ngacho (2018) in their study analyzed the impact of financial solvency and strength on competence of listed manufacturing companies of Kenya during 20112015. Financial health was measured by $\mathrm{Z}$ score model. Study revealed that debt-equity ratio as solvency proxy has negative and insignificant impact on financial performance. Among 9 firms, one firm was in grey zone, three firms were in distress zone and five firms were in safe zone. Egbunike, Ogbodo, \& Ojimadu (2019) studied association between financial distress and profitability of 21 firms of consumer goods sector listed in Nigerian stock exchange. Study found that return on asset was positively related but gross profit margin was negatively related with financial distress. Masum and Johora (2012) in their study has estimated the Z score of 4 ceramic companies of Bangladesh to assess the financial soundness during 2006-07 to 2010-11. Study showed that in initial year of the study period, two firms were in distress zone and two firms were in grey zone. The firms of distress zone entered into safe zone in 2010-11 which implies that financial soundness of ceramic companies were increasing gradually. Ikpesu and Eboiyehi (2018) has examined the impact of capital structure on financial distress of Nigerian manufacturing firmsin their research. Long term debt to asset ratio was used as the indicator of capital structure and Altman's Z score as for measuring the financial distress. Study found that long term debt to asset ratio has negative effect on financial distress while profitability, tangibility and firm age reduces financial distress. Sadiq, Kachollom, Dasuki, and Yusuf (2017) in their study revealed that appropriate composition of debt and equity capital maximize bank's return on investment.

\section{OBJECTIVE OF THE STUDY}

The fundamental objective of the study was to examine the effect of debt financing on financial distress measured by Altman's Z score. The distinctive aims are:

a. To critically examine the financial distress of companies by computing $\mathrm{Z}$ score as well as its individual component and make a comparative analysis between MNCs and local firms.

b. To explore the changes in $\mathrm{Z}$ score due to changes in debt of firms and make a comparative analysis between MNCs and local firms.

c. To test the significance of difference in $\mathrm{Z}$ scores between local firms and MNCs.

\section{HYPOTHESIS OF THE STUDY}

Null hypothesis $\left(\mathrm{H}_{0}\right)$ : $\mathrm{Z}$ scores of domestic companies do not significantly differ from that of MNCs 


\section{METHODOLOGY OF THE STUDY}

\section{Data and Sample}

Secondary and quantitative data were used in the study. Nature of data was Panel and collected from audited annual reports of manufacturing firms. Dhaka Stock Exchange (DSE) listed manufacturing companies constitute the population which was divided into two strata- local firms and MNCs. In manufacturing segment, listed MNCs operate in six industrial sectors, namely Pharmaceuticals \& Chemicals, Engineering, Food \& Allied, Tannery, Cement, and Fuel \& Power. From these industrial sectors seven MNCs and seven local firms were chosen by applying stratified sampling technique. Two firms were taken from Pharmaceuticals \& Chemicals industry and one firm from rest of five industrial sectors. Sample size was $14(7+7)$. Study period was from year 1996 to 2019.

\section{Data Analysis Technique}

Some descriptive statistics such as mean, standard deviation, and standard error were used to analyze data. Besides these, inferential statistic such as independent sample t-test has been used to test the significance of difference in $\mathrm{Z}$ scores of two groups.

\section{Model Specification and Variable Description}

Financial distress of a company is measured through Altman's Z-Score Model. Altman (1993) had developed Z-score Model to predict bankruptcy probability which is composed of the following function:

$\mathrm{Z}=1.2 \mathrm{X}_{1}+1.4 \mathrm{X}_{2}+3.3 \mathrm{X}_{3}+0.6 \mathrm{X}_{4}+1.0 \mathrm{X}_{5}$

Where $\mathrm{X}_{1}=$ Working capital/Total Assets, $\mathrm{X}_{2}=$ Retained Earnings/Total Assets

$\mathrm{X}_{3}=\mathrm{EBIT} /$ Total Assets,

$\mathrm{X}_{4}=$ Market Value of Equity/ Book value of Total Liabilities

$\mathrm{X}_{5}=$ Sales $/$ Total Assets

A score of $\mathrm{Z}$ less than 2.675 indicates that a firm has a $95 \%$ chance of becoming bankrupt within one year. The area between 1.81 and 2.99 should be thought of as grey area. Bankruptcy would be predicted if $Z \leq 1.81$ and non-bankruptcy if $Z \geq 2.99$.

Mean values of all variables in every year were determined to quantify the results. By two phases, grand mean value were determined. First, for each year, the arithmetic mean values of the above 5 predictor factors of all 7 firms were evaluated and then the response variable [ $\mathrm{Z}$ score] was determined for each year. Secondly, the average of yearly mean values of explanatory and explained variables of twenty four years (1996-2019) are estimated to obtain the broad mean value that is used to examine the effect of $4^{\text {th }}$ explanatory factor (Market Value of Equity / Book Value of Total Liabilities) on Z score.

\section{RESULTS AND DISCUSSION}

\section{Z-Scores \& Zones of Domestic Companies and MNCs}

Table 1 indicates that the mean $\mathrm{Z}$ scores of all local businesses was higher than 1.81 , which impliesthat either firms were in the gray area or in the protected zone where bankruptcy was not probable. Across most of the years, SPL's Z score was far higher than other firms, suggesting that the firm has a higher capacity to meet financial obligations than other firms. In most of the 
times, the POC's Z score was beyond 3, but it has been in the distress zone in recent times. Likewise, across the overall span, the Z score for AFL and AMCL was beyond 2 and it also exhibited a clear trend. Relatively significant variations are seen in companies' AAL and SPL and $\mathrm{Z}$ scores have decreased in recent years, but over the full duration, SPL was in a safe zone. In most years, since $\mathrm{Z}$ value was within 1.81 and 2.99 , the AAL was in the gray zone. This state can be seen in AMCL from 1998 to 2007 as well as in the early periods of the AFL. The highest average Z score in SPL was reported to be 8.3 and the least value of 2.78 in AFL was reported.

The Z-Score of MNCs in various periods is shown in Table 2. It is shown that Z scores of all firms are higher than 2.99 with the exception of some years, which implies that firms were in the safe area or much of the period there was no risk of insolvency. Across most of the BSC and HCL periods, the Z score was over 2.99. Over the entire period, GSK's and LBD's Z score were above 2.99. In many years, GSK's Z score was greater than other companies, which means that the financial solvency of the firm in those periods was higher than that of other firms. Throughout most of the periods, BSC and RBB's Z score was beyond 3 whereas that of GSK exceeds 5 across most of the periods. In SBD, relatively large variability is seen as a sudden rise and fall in the $\mathrm{Z}$ score from the table is reported. Owing to an unprecedented increase in the share price, the $Z$ scores of several firms grew significantly in 2010. Stability is seen in many of the MNCs, except this year. The highest mean Z score was reported in GSK, which was 6.72, and the least score in BSC was reported at 4.08.

\section{Comparison of Average Z-Score between Domestic Companies and MNCs}

The comparison of the average Z-Score between the two forms of companies is shown in Table 1 and 2. It is evident that $Z$ scores for MNCs were higher relative to those of local firms over the entire study period. The $\mathrm{Z}$ score variation was not very high. The $\mathrm{Z}$ score for MNCs was above 10 in 1996, but it subsequently declined and stayed steady at three to four until 2008. The score has been standing around 5 in recent periods. The mean $\mathrm{Z}$ score of local firms hovered around 3 until 2008 and the score has reduced in past few years since 2016. The overall mean $\mathrm{Z}$ score is evaluated by finding the arithmetic mean of the average $Z$ score across all 24 years. The average $\mathrm{Z}$ score for MNCs was 5,398, whereas that for local firms was 4,155.

\section{Analyzing the Effect of Leverage on $\mathrm{Z}$ score of Domestic Companies and MNCs}

Initially, the influence of the market value of equity to book value of the total liabilities ratio on the $\mathrm{Z}$ score is measured in order to objectively analyze the influence of leverage on the $\mathrm{Z}$ score of local companies and MNCs. The leverage effect on this ratio is then calculated.

Table 1. Z-Score and Zones of Domestic Companies

\begin{tabular}{|c|c|c|c|c|c|c|c|c|}
\hline Year & AAL & AFL & AMCL & BPL & CCL & POC & SPL & Avg. \\
\hline \multirow{2}{*}{1996} & 1.923 & 2.316 & 6.305 & 3.565 & 4.645 & 4.687 & 6.688 & 4.304 \\
\cline { 2 - 9 } & Grey & Grey & Safe & Safe & Safe & Safe & Safe & Grey \\
\hline \multirow{2}{*}{1997} & 2.238 & 2.354 & 8.054 & 3.911 & 7.754 & 4.203 & 7.975 & 5.213 \\
\cline { 2 - 9 } & Grey & Grey & Safe & Safe & Safe & Safe & Safe & Grey \\
\hline \multirow{2}{*}{1998} & 2.415 & 2.347 & 2.312 & 2.446 & 8.424 & 4.262 & 7.488 & 4.242 \\
\cline { 2 - 9 } & Grey & Grey & Grey & Grey & Safe & Safe & Safe & Grey \\
\hline \multirow{20}{*}{$\mathbf{2 0 0 0}$} & 2.527 & 2.286 & 2.620 & 2.381 & 5.469 & 3.874 & 3.653 & 3.259 \\
\cline { 2 - 9 } & Grey & Grey & Grey & Grey & Safe & Safe & Safe & Grey \\
\hline
\end{tabular}




\begin{tabular}{|c|c|c|c|c|c|c|c|c|}
\hline & Grey & Grey & Grey & Grey & Safe & Safe & Safe & Grey \\
\hline \multirow[t]{2}{*}{2001} & 2.519 & 2.000 & 2.801 & 2.198 & 4.784 & 3.181 & 4.303 & 3.112 \\
\hline & Grey & Grey & Grey & Grey & Safe & Safe & Safe & Grey \\
\hline \multirow[t]{2}{*}{2002} & 2.529 & 2.064 & 2.607 & 2.003 & 3.319 & 3.109 & 4.097 & 2.818 \\
\hline & Grey & Grey & Grey & Grey & Safe & Safe & Safe & Grey \\
\hline \multirow[t]{2}{*}{2003} & 3.141 & 2.456 & 2.470 & 1.523 & 2.191 & 3.137 & 4.313 & 2.747 \\
\hline & Safe & Grey & Grey & Distress & Grey & Safe & Safe & Safe \\
\hline \multirow[t]{2}{*}{2004} & 2.454 & 2.972 & 2.617 & 1.782 & 1.755 & 3.202 & 7.722 & 3.215 \\
\hline & Grey & Grey & Grey & Distress & Distress & Safe & Safe & Grey \\
\hline \multirow[t]{2}{*}{2005} & 2.502 & 3.474 & 2.641 & 2.448 & 1.961 & 3.877 & 5.956 & 3.266 \\
\hline & Grey & Safe & Grey & Grey & Distress & Safe & Safe & Grey \\
\hline \multirow[t]{2}{*}{2006} & 2.420 & 3.181 & 2.649 & 2.135 & 2.495 & 3.285 & 4.695 & 2.980 \\
\hline & Grey & Safe & Grey & Grey & Grey & Safe & Safe & Grey \\
\hline \multirow[t]{2}{*}{2007} & 2.062 & 3.431 & 2.907 & 2.258 & 3.090 & 3.371 & 6.024 & 3.306 \\
\hline & Grey & Safe & Grey & Grey & Safe & Safe & Safe & Grey \\
\hline \multirow[t]{2}{*}{2008} & 2.361 & 4.167 & 3.529 & 2.980 & 2.740 & 4.128 & 7.043 & 3.850 \\
\hline & Grey & Safe & Safe & Grey & Grey & Safe & Safe & Grey \\
\hline \multirow[t]{2}{*}{2009} & 3.796 & 3.978 & 3.758 & 2.931 & 3.042 & 4.347 & 8.975 & 4.404 \\
\hline & Safe & Safe & Safe & Grey & Safe & Safe & Safe & Safe \\
\hline \multirow[t]{2}{*}{2010} & 22.806 & 3.771 & 3.867 & 5.094 & 11.663 & 3.928 & 12.073 & 9.029 \\
\hline & Safe & Safe & Safe & Safe & Safe & Safe & Safe & Safe \\
\hline \multirow[t]{2}{*}{2011} & 10.113 & 3.300 & 2.786 & 4.130 & 5.171 & 3.547 & 2.950 & 4.571 \\
\hline & Safe & Safe & Grey & Safe & Safe & Safe & Grey & Safe \\
\hline \multirow[t]{2}{*}{2012} & 5.848 & 3.059 & 3.816 & 3.584 & 4.078 & 3.357 & 9.130 & 4.696 \\
\hline & Safe & Safe & Safe & Safe & Safe & Safe & Safe & Safe \\
\hline \multirow[t]{2}{*}{2013} & 4.562 & 2.989 & 4.429 & 3.009 & 4.107 & 3.386 & 11.442 & 4.846 \\
\hline & Safe & Safe & Safe & Safe & Safe & Safe & Safe & Safe \\
\hline \multirow[t]{2}{*}{2014} & 4.147 & 2.713 & 5.207 & 2.983 & 3.644 & 3.338 & 20.339 & 6.053 \\
\hline & Safe & Grey & Safe & Grey & Safe & Safe & Safe & Safe \\
\hline \multirow{2}{*}{2015} & 2.600 & 2.520 & 3.690 & 3.376 & 3.198 & 3.068 & 28.341 & 6.685 \\
\hline & Grey & Grey & Safe & Safe & Safe & Safe & Safe & Grey \\
\hline \multirow{2}{*}{2016} & 2.555 & 2.249 & 3.829 & 3.641 & 2.211 & 1.811 & 9.134 & 3.633 \\
\hline & Grey & Grey & Safe & Safe & Grey & Grey & Safe & Grey \\
\hline \multirow{2}{*}{2017} & 2.360 & 2.349 & 4.184 & 3.951 & 1.969 & 1.119 & 8.488 & 3.489 \\
\hline & Grey & Grey & Safe & Safe & Grey & Distress & Safe & Grey \\
\hline \multirow{2}{*}{2018} & 1.956 & 2.368 & 4.600 & 2.983 & 2.209 & 1.446 & 6.503 & 3.152 \\
\hline & Grey & Grey & Safe & Grey & Grey & Distress & Safe & Grey \\
\hline \multirow{2}{*}{2019} & 1.517 & 2.227 & 4.952 & 2.586 & 2.691 & 1.505 & 8.187 & 3.381 \\
\hline & Distress & Grey & Safe & Grey & Grey & Distress & Safe & Distress \\
\hline \multirow[t]{2}{*}{ Average } & 3.909 & 2.785 & 3.725 & 2.936 & 4.133 & 3.291 & 8.310 & 4.155 \\
\hline & Safe & Grey & Safe & Grey & Safe & Safe & Safe & Safe \\
\hline
\end{tabular}

Source: Derived from Annual Reports (1996-2019) and DSE Reports

Table 2. Z-Scores and Zones of MNCs

\begin{tabular}{|c|c|c|c|c|c|c|c|c|}
\hline Year & BSC & BATB & GSK & HCL & LBD & RBB & SBD & Avg. \\
\hline \multirow{2}{*}{1996} & 4.875 & 6.105 & 11.633 & 8.539 & 7.584 & 8.970 & 23.548 & 10.179 \\
\cline { 2 - 9 } & Safe & Safe & Safe & Safe & Safe & Safe & Safe & Safe \\
\hline \multirow{2}{*}{1997} & 3.646 & 3.934 & 9.308 & 8.757 & 6.086 & 7.211 & 21.361 & 8.615 \\
\cline { 2 - 9 } & Safe & Safe & Safe & Safe & Safe & Safe & Safe & Safe \\
\hline
\end{tabular}




\begin{tabular}{|c|c|c|c|c|c|c|c|c|}
\hline \multirow[t]{2}{*}{1998} & 3.155 & 3.006 & 5.604 & 3.608 & 3.251 & 3.991 & 9.347 & 4.566 \\
\hline & Safe & Safe & Safe & Safe & Safe & Safe & Safe & Safe \\
\hline \multirow[t]{2}{*}{1999} & 3.079 & 2.477 & 5.564 & 4.143 & 3.087 & 3.566 & 5.684 & 3.943 \\
\hline & Safe & Grey & Safe & Safe & Safe & Safe & Safe & Safe \\
\hline \multirow{2}{*}{2000} & 3.095 & 3.016 & 7.224 & 6.788 & 3.086 & 4.547 & 6.121 & 4.840 \\
\hline & Safe & Safe & Safe & Safe & Safe & Safe & Safe & Safe \\
\hline \multirow[t]{2}{*}{2001} & 3.108 & 3.866 & 5.837 & 5.321 & 3.061 & 3.086 & 5.105 & 4.198 \\
\hline & Safe & Safe & Safe & Safe & Safe & Safe & Safe & Safe \\
\hline \multirow[t]{2}{*}{2002} & 3.180 & 2.772 & 5.501 & 3.648 & 3.599 & 2.078 & 5.272 & 3.721 \\
\hline & Safe & Grey & Safe & Safe & Safe & Grey & Safe & Safe \\
\hline \multirow[t]{2}{*}{2003} & 3.359 & 2.510 & 3.887 & 1.298 & 3.991 & 3.485 & 5.200 & 3.390 \\
\hline & Safe & Grey & Safe & Distress & Safe & Safe & Safe & Safe \\
\hline \multirow[t]{2}{*}{2004} & 3.080 & 2.931 & 6.518 & 1.673 & 3.882 & 4.386 & 4.248 & 3.817 \\
\hline & Safe & Grey & Safe & Distress & Safe & Safe & Safe & Safe \\
\hline \multirow[t]{2}{*}{2005} & 3.255 & 2.066 & 7.140 & 1.913 & 3.596 & 4.430 & 2.437 & 3.548 \\
\hline & Safe & Grey & Safe & Grey & Safe & Safe & Grey & Safe \\
\hline \multirow[t]{2}{*}{2006} & 2.968 & 1.737 & 5.776 & 2.563 & 3.569 & 5.104 & 2.036 & 3.393 \\
\hline & Grey & Distress & Safe & Grey & Safe & Safe & Grey & Grey \\
\hline \multirow[t]{2}{*}{2007} & 3.152 & 2.397 & 6.264 & 3.182 & 4.544 & 4.916 & 2.259 & 3.816 \\
\hline & Safe & Grey & Safe & Safe & Safe & Safe & Grey & Safe \\
\hline \multirow[t]{2}{*}{2008} & 4.009 & 3.209 & 6.332 & 3.527 & 5.964 & 4.923 & 2.953 & 4.417 \\
\hline & Safe & Safe & Safe & Safe & Safe & Safe & Grey & Safe \\
\hline \multirow[t]{2}{*}{2009} & 4.043 & 3.512 & 8.488 & 4.666 & 6.693 & 5.376 & 4.734 & 5.359 \\
\hline & Safe & Safe & Safe & Safe & Safe & Safe & Safe & Safe \\
\hline \multirow[t]{2}{*}{2010} & 5.305 & 5.392 & 12.726 & 6.670 & 10.404 & 11.701 & 11.201 & 9.057 \\
\hline & Safe & Safe & Safe & Safe & Safe & Safe & Safe & Safe \\
\hline \multirow[t]{2}{*}{2011} & 4.695 & 5.636 & 6.806 & 4.830 & 9.608 & 5.976 & 5.856 & 6.201 \\
\hline & Safe & Safe & Safe & Safe & Safe & Safe & Safe & Safe \\
\hline \multirow[t]{2}{*}{2012} & 4.245 & 5.829 & 4.710 & 5.057 & 7.215 & 4.876 & 4.430 & 5.195 \\
\hline & Safe & Safe & Safe & Safe & Safe & Safe & Safe & Safe \\
\hline \multirow[t]{2}{*}{2013} & 4.444 & 7.478 & 4.730 & 5.642 & 7.627 & 4.762 & 5.351 & 5.719 \\
\hline & Safe & Safe & Safe & Safe & Safe & Safe & Safe & Safe \\
\hline \multirow[t]{2}{*}{2014} & 5.507 & 8.061 & 6.291 & 6.761 & 9.056 & 5.856 & 5.129 & 6.666 \\
\hline & Safe & Safe & Safe & Safe & Safe & Safe & Safe & Safe \\
\hline \multirow[t]{2}{*}{2015} & 7.155 & 9.791 & 6.910 & 6.854 & 9.336 & 8.049 & 5.187 & 7.612 \\
\hline & Safe & Safe & Safe & Safe & Safe & Safe & Safe & Safe \\
\hline \multirow[t]{2}{*}{2016} & 5.598 & 4.710 & 7.227 & 6.090 & 7.217 & 5.992 & 3.164 & 5.714 \\
\hline & Safe & Safe & Safe & Safe & Safe & Safe & Safe & Safe \\
\hline \multirow[t]{2}{*}{2017} & 5.194 & 4.012 & 5.250 & 5.907 & 7.247 & 5.896 & 3.242 & 5.250 \\
\hline & Safe & Safe & Safe & Safe & Safe & Safe & Safe & Safe \\
\hline \multirow[t]{2}{*}{2018} & 4.582 & 4.032 & 5.730 & 5.098 & 6.817 & 5.869 & 2.931 & 5.008 \\
\hline & Safe & Safe & Safe & Safe & Safe & Safe & Grey & Safe \\
\hline \multirow[t]{2}{*}{2019} & 3.341 & 8.701 & 5.836 & 2.345 & 6.685 & 6.925 & 3.402 & 5.319 \\
\hline & Safe & Safe & Safe & Safe & Safe & Safe & Safe & Safe \\
\hline Average & 4.086 & 4.466 & 6.720 & 4.787 & 5.967 & 5.499 & 6.258 & 5.398 \\
\hline & Safe & Safe & Safe & Safe & Safe & Safe & Safe & Safe \\
\hline
\end{tabular}

Source: Derived from Derived from Annual Reports (1996-2019) and DSE Reports 
Table 3. Average Values of Z Score and its Components

\begin{tabular}{|c|c|c|c|c|c|c|}
\hline Year & WC/TA & RE/TA & EBIT/TA & MV(E)/BV(TL) & TS/TA & Z score \\
\hline \multicolumn{7}{|c|}{ Domestic Companies } \\
\hline 1996 & 0.618 & 0.094 & 0.082 & 3.620 & 0.989 & 4.304 \\
\hline 1997 & 0.634 & 0.127 & 0.089 & 5.034 & 0.961 & 5.213 \\
\hline 1998 & 0.610 & 0.142 & 0.105 & 3.173 & 1.062 & 4.242 \\
\hline 1999 & 0.566 & 0.171 & 0.107 & 1.637 & 1.007 & 3.259 \\
\hline 2000 & 0.595 & 0.192 & 0.113 & 1.861 & 1.007 & 3.481 \\
\hline 2001 & 0.604 & 0.202 & 0.109 & 1.316 & 0.955 & 3.112 \\
\hline 2002 & 0.605 & 0.211 & 0.089 & 0.938 & 0.941 & 2.819 \\
\hline 2003 & 0.587 & 0.198 & 0.089 & 0.825 & 0.977 & 2.747 \\
\hline 2004 & 0.605 & 0.186 & 0.081 & 1.690 & 0.948 & 3.215 \\
\hline 2005 & 0.631 & 0.191 & 0.089 & 1.395 & 1.111 & 3.265 \\
\hline 2006 & 0.640 & 0.200 & 0.085 & 1.039 & 1.027 & 2.980 \\
\hline 2007 & 0.634 & 0.207 & 0.092 & 1.538 & 1.029 & 3.306 \\
\hline 2008 & 0.628 & 0.216 & 0.085 & 2.218 & 1.181 & 3.850 \\
\hline 2009 & 0.589 & 0.229 & 0.127 & 3.091 & 1.102 & 4.404 \\
\hline 2010 & 0.585 & 0.283 & 0.122 & 10.970 & 0.946 & 9.029 \\
\hline 2011 & 0.580 & 0.307 & 0.117 & 3.595 & 0.902 & 4.571 \\
\hline 2012 & 0.592 & 0.308 & 0.116 & 3.699 & 0.954 & 4.696 \\
\hline 2013 & 0.580 & 0.317 & 0.117 & 3.978 & 0.935 & 4.846 \\
\hline 2014 & 0.583 & 0.318 & 0.106 & 6.077 & 0.913 & 6.053 \\
\hline 2015 & 0.540 & 0.316 & 0.107 & 7.279 & 0.875 & 6.685 \\
\hline 2016 & 0.618 & 0.278 & 0.079 & 2.683 & 0.632 & 0.618 \\
\hline 2017 & 0.562 & 0.287 & 0.071 & 2.535 & 0.657 & 0.562 \\
\hline 2018 & 0.600 & 0.284 & 0.063 & 1.921 & 0.673 & 0.600 \\
\hline 2019 & 0.632 & 0.293 & 0.063 & 2.193 & 0.687 & 0.632 \\
\hline Avg & 0.601 & 0.231 & 0.096 & 3.096 & 0.936 & 4.155 \\
\hline \multicolumn{7}{|c|}{ MNCs } \\
\hline 1996 & 0.588 & 0.402 & 0.176 & 12.848 & 1.341 & 11.507 \\
\hline 1997 & 0.577 & 0.373 & 0.174 & 10.865 & 1.309 & 9.911 \\
\hline 1998 & 0.559 & 0.360 & 0.179 & 4.387 & 1.269 & 5.822 \\
\hline 1999 & 0.558 & 0.404 & 0.177 & 3.275 & 1.212 & 5.143 \\
\hline 2000 & 0.561 & 0.452 & 0.237 & 4.278 & 1.422 & 6.247 \\
\hline 2001 & 0.584 & 0.431 & 0.188 & 3.366 & 1.331 & 5.515 \\
\hline 2002 & 0.580 & 0.412 & 0.138 & 3.081 & 1.287 & 4.995 \\
\hline 2003 & 0.546 & 0.401 & 0.149 & 2.581 & 1.291 & 4.668 \\
\hline 2004 & 0.550 & 0.396 & 0.136 & 3.254 & 1.299 & 5.103 \\
\hline 2005 & 0.586 & 0.390 & 0.124 & 2.919 & 1.353 & 4.887 \\
\hline 2006 & 0.614 & 0.415 & 0.157 & 2.479 & 1.559 & 4.937 \\
\hline 2007 & 0.654 & 0.415 & 0.178 & 2.928 & 1.513 & 5.314 \\
\hline 2008 & 0.700 & 0.426 & 0.203 & 3.592 & 1.495 & 5.896 \\
\hline 2009 & 0.706 & 0.455 & 0.256 & 4.727 & 1.574 & 6.917 \\
\hline 2010 & 0.718 & 0.510 & 0.309 & 10.058 & 1.606 & 10.647 \\
\hline 2011 & 0.702 & 0.470 & 0.233 & 5.848 & 1.656 & 7.840 \\
\hline 2012 & 0.705 & 0.479 & 0.228 & 4.196 & 1.669 & 6.846 \\
\hline 2013 & 0.714 & 0.494 & 0.244 & 4.574 & 1.528 & 7.232 \\
\hline 2014 & 0.714 & 0.421 & 0.238 & 6.122 & 1.559 & 8.209 \\
\hline 2015 & 0.689 & 0.424 & 0.262 & 8.850 & 1.572 & 9.168 \\
\hline 2016 & 0.705 & 0.386 & 0.239 & 5.876 & 1.346 & 7.047 \\
\hline 2017 & 0.689 & 0.384 & 0.232 & 5.175 & 1.337 & 6.573 \\
\hline 2018 & 0.685 & 0.376 & 0.229 & 4.820 & 1.276 & 6.272 \\
\hline 2019 & 0.628 & 0.400 & 0.211 & 5.499 & 1.159 & 6.467 \\
\hline Avg & 0.638 & 0.420 & 0.204 & 5.595 & 1.415 & 6.799 \\
\hline
\end{tabular}

Source: Derived from Annual Reports (1996-2019) 
Annual reports are used to calculate the average values of the above five explanatory variables each year (1996-2019). The very last column of Table 3 displays the overall Z score of domestic firms and MNCs each year, using the mean of explanatory variable values of the seven corporations. The mean values of the explanatory variables of seven local firms per year are displayed in each row of each column of Table 3, and the $\mathrm{Z}$ score is calculated applying the formula. The very last row represents the grand mean of the average scores for all 24 years. The model for local companies is like as follows after placing the final mean values:

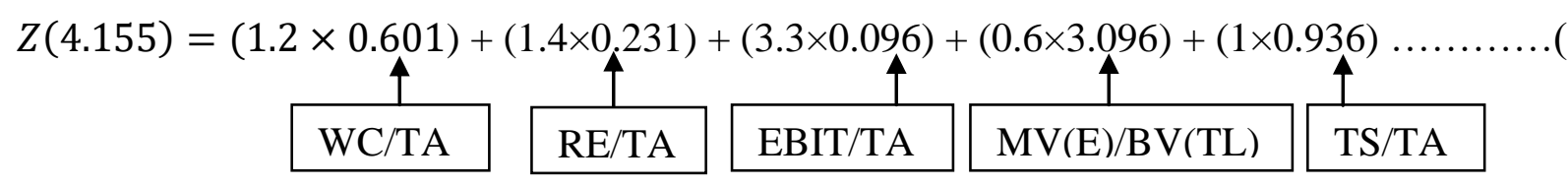

The model of MNCs becomes the following after placing the grand mean value:

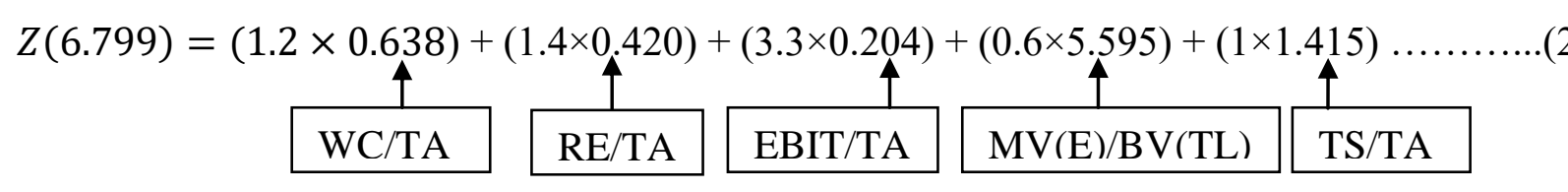

It is observed from the models (1) and (2) that the shift in $\mathrm{MV}(\mathrm{E}) / \mathrm{BV}(\mathrm{TL})$ triggered the $\mathrm{Z}$ score to vary.The shift in Z-score is observed by adjusting $\mathrm{MV}(\mathrm{E}) / \mathrm{BV}(\mathrm{TL})$ by 1 percent, 5 percent and 10 percent, and it is evident in Table 4 that the increase in $\mathrm{MV}(\mathrm{E}) / \mathrm{BV}(\mathrm{TL})$ results in an increase in Z-score and vice versa. The rate of Z-score increase and decrease is the same for a given percentage change in $\mathrm{MV}$ (E)/BV (TL). For domestic industries, if MV (E)/BV (TL) increases by 1 percent, the $\mathrm{Z}$ score increases by 0.4 percent or 0.02 while 5 percent and 10 percent increase leads to an increase of 2.2 percent or 0.09 and a $Z$ score rise of 4.5 percent or 0.195 , respectively. From table 4, it is obvious that 1 percent increase in MV(E)/BV(TL) leads to 0.49 percent or 0.033 increase in Z-score in the case of MNCs, while 5 percent and 10 percent increase lead to 2.47 percent or 0.168 increase and 4.94 percent or rise in Z-score respectively.

Table 4. Impact of MV(E) / BV(TL) on Z Score of Companies

\begin{tabular}{|l|c|c|c|c|c|}
\hline $\begin{array}{c}\text { \% change in MV } \\
\text { (E) / BV (TL) }\end{array}$ & $\begin{array}{c}\text { New MV (E) } \\
\text { / BV (TL) }\end{array}$ & $\begin{array}{c}\text { New } \\
\text { Z-score }\end{array}$ & $\begin{array}{c}\text { Existing } \\
\text { Z-score }\end{array}$ & $\begin{array}{c}\text { change in } \\
\text { Z-score }\end{array}$ & $\begin{array}{c}\text { \% change } \\
\text { in Z-score }\end{array}$ \\
\hline \multicolumn{7}{|c|}{ Domestic Companies } \\
\hline Increase by 1\% & 3.12696 & 4.174 & 4.155 & 0.019 & 0.4 \\
\hline Decrease by 1\% & 3.06504 & 4.136 & 4.155 & -0.019 & -0.4 \\
\hline Increase by 5\% & 3.2508 & 4.248 & 4.155 & 0.093 & 2.2 \\
\hline Decrease by 5\% & 2.9412 & 4.062 & 4.155 & -0.093 & -2.2 \\
\hline Increase by 10\% & 3.4056 & 4.341 & 4.155 & 0.186 & 4.47 \\
\hline Decrease by 10\% & 2.7864 & 3.969 & 4.155 & -0.186 & -4.47 \\
\hline \multicolumn{7}{|c|}{ MNCs } \\
\hline Increase by 1\% & 5.65095 & 6.832 & 6.799 & 0.033 & 0.485 \\
\hline Decrease by 1\% & 5.53905 & 6.765 & 6.799 & -0.034 & -0.500 \\
\hline Increase by 5\% & 5.87475 & 6.967 & 6.799 & 0.168 & 2.471 \\
\hline Decrease by 5\% & 5.31525 & 6.631 & 6.799 & -0.168 & -2.471 \\
\hline Increase by 10\% & 6.1545 & 7.135 & 6.799 & 0.336 & 4.941 \\
\hline Decrease by 10\% & 5.0355 & 6.463 & 6.799 & -0.336 & -4.941 \\
\hline
\end{tabular}

Source: Derived from Z Score Model Note: Compiled by the researcher 
Currently, each company's gross borrowing is valued at variations of 1 percent, 5 percent and 10 percent each year, and a new ratio of Equity/Book Value of Total Liabilities is calculated. The annual average of this ratio at that point is determined by taking the annual average of seven local companies. The current average of this ratio is then assessed by taking into account the mean of the average value for all twenty four years. The shift in debt increases the total liabilities' book value, which ultimately changes the ration of the $\mathrm{MV}(\mathrm{E}) / \mathrm{BV}$ (TL) in the opposite direction. In the $\mathrm{Z}$ score equation, a new value is placed to evaluate the impact of the leverage shift on the $\mathrm{Z}$ score. The average TD in thecase of local firms is Tk.5097.92 million, representing $55.20 \%$ of TL(Average TL is Tk. 9233.76 million). The average TD in the case of MNCs is Tk. 332.42 million, representing 13.67 percent of TL (Average TL is Tk. 2431.45 million). The effect of the shift in leverage on the $\mathrm{Z}$ score is shown in Table 5.

Table 5. Impact of Debt on $\mathrm{Z}$ score

\begin{tabular}{|l|c|c|c|c|c|c|}
\hline \% change in TD & $\begin{array}{c}\text { \% change } \\
\text { in TL }\end{array}$ & $\begin{array}{c}\text { New MV } \\
\text { (E) / BV } \\
\text { (TL) }\end{array}$ & $\begin{array}{c}\text { New } \\
\text { Z-score }\end{array}$ & $\begin{array}{c}\text { Existing } \\
\text { Z-score }\end{array}$ & $\begin{array}{c}\text { change } \\
\text { in Z- } \\
\text { score }\end{array}$ & $\begin{array}{c}\text { \% } \\
\text { change } \\
\text { in Z- } \\
\text { score }\end{array}$ \\
\hline \multicolumn{7}{|c|}{ Domestic Companies } \\
\hline Increase by 1\% & $0.552 \%$ & 3.0790 & 4.145 & 4.155 & -0.010 & -0.240 \\
\hline Decrease by 1\% & $-0.552 \%$ & 3.1131 & 4.165 & 4.155 & 0.010 & 0.240 \\
\hline Increase by 5\% & $2.76 \%$ & 3.0128 & 4.105 & 4.155 & -0.050 & -1.20 \\
\hline Decrease by 5\% & $-2.76 \%$ & 3.1838 & 4.208 & 4.155 & 0.053 & 1.27 \\
\hline Increase by 10\% & $5.52 \%$ & 2.9340 & 4.058 & 4.155 & -0.097 & -2.33 \\
\hline Decrease by 10\% & $-5.52 \%$ & 3.2768 & 4.263 & 4.155 & 0.108 & 2.59 \\
\hline \multicolumn{7}{|c|}{ MNCs } \\
\hline Increase by 1\% & 0.1367 & 5.587 & 6.794 & 6.799 & -0.005 & -0.073 \\
\hline Decrease by 1\% & -0.1367 & 5.602 & 6.803 & 6.799 & 0.004 & 0.058 \\
\hline Increase by 5\% & 0.6835 & 5.557 & 6.776 & 6.799 & -0.023 & -0.338 \\
\hline Decrease by 5\% & -0.6835 & 5.633 & 6.822 & 6.799 & 0.023 & 0.338 \\
\hline Increase by 10\% & 1.367 & 5.519 & 6.754 & 6.799 & -0.045 & -0.661 \\
\hline Decrease by 10\% & -1.367 & 5.672 & 6.845 & 6.799 & 0.046 & 0.676 \\
\hline
\end{tabular}

Source: Derived from Z Score Model

Note: Compiled by the researcher

Table 5 shows that the $\mathrm{Z}$ score and total debt have an inverse relationship, which implies that decline of debt would enhance $\mathrm{Z}$ score and vice versa. For local companies, $\mathrm{Z}$ decreases by 0.01 or 0.24 percent if the overall debt rises by 1 percent. A 10 percent increase in total debt decreases $\mathrm{Z}$ score by 0.097 or 2.33 percent while 10 percent rise in debt decreases $\mathrm{Z}$ score by 0.108 or 2.59 percent. With MNCs, for a 1 percent increase in overall debt, the Z score decreases by 0.005 or 0.073 percent. A $10 \%$ increase in total debt reduces the $\mathrm{Z}$ score by 0.045 or 0.661 percent, while a $10 \%$ decrease in total debt raises the $\mathrm{Z}$ score by 0.046 or 0.676 percent.

\section{Comparison of Effect of Leverage on $Z$ Score}

Table 5 revealed that the $Z$ score's responsiveness to debt adjustment is higher for local companies as the change and the percent change in local companies' $Z$ score is greater than that of MNCs. The Z score of local companies increases by 0.01 if debt shifts by $1 \%$ and the $\mathrm{Z}$ score shifts by 0.005 for equal shifts in debt of MNCs. Similarly, in the context of local companies, the 
10 percent decline in debt enhances $\mathrm{Z}$ score by 0.108 or 2.59 percent, while the MNC's $\mathrm{Z}$ score enhances by 0.046 or 0.676 percent for the similar amount of debt decline.

\section{Test of Hypothesis}

Independent sample t-test have been applied to test the null hypothesis. The test is used to evaluate the significance of variation in $\mathrm{Z}$ score between domestic companies and MNCs. The following table shows the result of t-test. From the table it is seen that in both assumptions of variances, the $p$-value of t-statistic is 0.000 which is less than 0.01 . It indicates that the null hypothesis is rejected which means that there is significant difference between $\mathrm{Z}$ scores of domestic firms and MNCs.

Table 6. Independent Samples t-Test

\begin{tabular}{|c|c|c|c|c|c|c|c|c|c|c|}
\hline & \multicolumn{2}{|c|}{$\begin{array}{c}\text { Levene's } \\
\text { Test for } \\
\text { Equality } \\
\text { of } \\
\text { Variances }\end{array}$} & \multicolumn{7}{|c|}{ t-test for Equality of Means } \\
\hline & & \multirow[t]{2}{*}{$\mathrm{F}$} & \multirow[t]{2}{*}{ Sig. } & \multirow[t]{2}{*}{$\mathrm{t}$} & \multirow[t]{2}{*}{$\mathrm{df}$} & \multirow{2}{*}{$\begin{array}{l}\text { Sig. } \\
\text { (2- } \\
\text { tailed) }\end{array}$} & \multirow[t]{2}{*}{$\begin{array}{c}\text { Mean } \\
\text { Difference }\end{array}$} & \multirow[t]{2}{*}{$\begin{array}{l}\text { Std. Error } \\
\text { Difference }\end{array}$} & \multicolumn{2}{|c|}{$\begin{array}{c}95 \% \text { C.I. of the } \\
\text { Difference }\end{array}$} \\
\hline & & & & & & & & & Lower & Upper \\
\hline \multirow[t]{2}{*}{$\begin{array}{l}\mathrm{Z} \\
\text { score }\end{array}$} & $\begin{array}{l}\text { Equal } \\
\text { variances } \\
\text { assumed } \\
\end{array}$ & .000 & .990 & -3.63 & 334 & $.000^{*}$ & -1.2421 & .3420 & $-\overline{1.9150}$ & -.5692 \\
\hline & $\begin{array}{l}\text { Equal } \\
\text { variances } \\
\text { not assumed }\end{array}$ & & & -3.63 & 325 & $.000^{*}$ & -1.2421 & .3420 & $-\overline{1.9151}$ & $\begin{array}{l}- \\
.5691\end{array}$ \\
\hline
\end{tabular}

Source: Authors' own computation, Note: *significant at 1\% level

\section{RECOMMENDATIONS AND CONCLUSION}

Liability management is an important arena of corporate finance and it is critical for a manufacturing firm because financial distress, financial risk, solvency, and long run survival of a firm depends on it. By comparing 168 firm-year observations for each group it is seen that in case of domestic companies there are 8 observations in distress zone, 64 in grey zone and 96 in safe zone while in case of MNCs the figures are 3,15 and 150 respectively. Yearly $\mathrm{Z}$ scores of MNCs are significantly greater compared to that of domestic firms. From observing mean $\mathrm{Z}$ score of individual firms, it is seen that five domestic firms are in safe zone but two are in grey zone while in case of MNCs all firms are in safe zone. These findings are supported by the fact that market value of equity is more than 3 times of liability in case of domestic companies while it is more than 5 times of liability in case of MNCs. Domestic companies can increase their Z score by reducing debt in their capital structure. Besides it, by observing individual components of $\mathrm{Z}$ score it can be said that domestic companies basic earning power (EBIT/TA), retained earnings to asset (RE/TA) and asset utilization (TS/TA) ratio are much lower than MNCs and Z score can be enhanced by improving these ratios. Further studies can be conducted on nonmanufacturing companies to assess financial distress by applying different models and different industrial sectors can be compared with each other. 


\section{ACKNOWLEDGEMENTS}

The authors are indebted to managers of sample firms at different levels as well as to authority of the Dhaka Stock Exchange of Bangladesh for providing secondary data and reports.

\section{REFERENCES}

Aasen, M. R. (fall 2011). Applying Altman's Z-score to the financial crisis: An empirical study of financial distress on Oslo stock exchange (Master's thesis in financial economics), Norwegian School of Economics, Norway.

Afrina, T., Beg, T. H., Zayed, N. M., Hossain, M. S., \& Shahi, S. H. (2020). An analysis of the effects of corona virus (COVID-19) on international financial derivatives market, 2020. Indian Journal of Finance and Banking, 4(2), 93-98. https://doi.org/10.46281/ijfb.v4i2.757

Akani, H. W., \& Ifechi, K. N. J. (2017). Effects of capital structure and board structure on corporate performance of selected firms in Nigeria. Indian Journal of Finance and Banking, 1(2), 1-16.https://doi.org/10.46281/ijfb.v1i2.85

Ali, M. R., Rahman, M. M., \& Mahmud, M. S. (2016). Financial soundness of textile industry: Altman Z-score measurement. Journal of Science and Technology, 14, 8-17. Retrieved from https://jst.hstu.ac.bd/assets_vcc/files/vol_14/2_14_jst_15-18.pdf

Altman, E. I. (1993). Corporate Financial Distress and Bankruptcy. New York: John Wiley \& Sons, ch.3, quoted in Stephen H. Penman, Financial Statement Analysis and Security Valuation (3rd ed.). New Delhi, India: Tata McGraw-Hill Publishing Co. Ltd., 2008, p. 730.

Altman, E. I. (1983). Corporate Financial Distress: A Complete Guide to Predicting, Avoiding and Dealing with Bankruptcy. New York: John Wiley \& Sons.

Anjum, S. (2012). Business bankruptcy prediction models: A significant study of the Altman's Z-score model. Asian journal of management research, 3(1), 212-219.

Barman, B. (2020, April 25). Most MNCs see surge in 2019 earnings. The Financial Express. Retrieved from https://www.thefinancialexpress.com.bd/stock

Black's Law Dictionary, $5^{\text {th }}$ ed. (St. Paul Minn.: West Publishing Company), 716, quoted in Ross, Westerfield, and Jaffe, Corporate Finance, 830-831.

Brealey, R. A., \& Myres, S. C. (1996). Principles of Corporate Finance (5 ${ }^{\text {th }}$ ed.). New York: McGraw Hill Companies, pp. 484-486.

Egbunike, F. C., Ogbodo, C. O., \& Ojimadu, J. O. (2019). The Effect of Financial Distress on Corporate Profitability: A Panel Estimated Generalized Least Squares (EGLS) Approach. Journal of Global Accounting, 6(1), 24-44. Retrieved from http://unizikjga.com/PDF-files/Volume-6-No-1-2019/24-44.pdf 
Gopalakrishnan, M. M., Gupta, A., Raja, M., Reddy, R. V., \& Subbarao, A. N. (2019). Bankruptcy prediction for steel industry in India using Altman $\mathrm{Z}$ score model. International Journal of Production Technology and Management (IJPTM), 10(1), 87102. $\quad$ Retrieved from http://www.iaeme.com/ijptm/issues.asp?JType=IJPTM\&VType=10\&IType=1

Hillary, O. K., Nyang'au, A., \& Ngacho, C. (2018). Effects of financial distress on financial performance of manufacturing firms listed in Nairobi securities exchange. International Journals of Academics \& Research, 1(1), 211-220. Retrieved from https://storage.googleapis.com/wzukusers/user34065638/documents/5bc8e45629b7faM6CRmb/19IBM\%20Journals\%20Vol1\%20Issue1\%2019.pdf

Iheduru, N. G., \& Okoro, C. U. (2018). Macroeconomic variables and retained earnings of quoted manufacturing firms in Nigeria: A time variant study. International Journal of Accounting \& Finance Review, 3(1), 33-47. https://doi.org/10.46281/ijafr.v3i1.29

Ikpesu, F., \& Eboiyehi, O. C. (2018). Capital structure and corporate financial distress of manufacturing firms in Nigeria. Journal of Accounting and Taxation, 10(7), 78-84. http://dx.doi.org/10.5897/JAT2018.0309

Jahur, M S., \&Quadir, S. (2012). Financial distress in small and medium enterprises (SMEs) of Bangladesh: Determinants and remedial measures. Economia: Seria Management, 15. Retrieved from https://www.researchgate.net/publication/254449281

Janardhanan, A. K., \& Uma, V. R. (2020). The role of internal control and firm-specific characteristics on firm value: Evidence from Indian financial services sector. Indian Journal of Finance and Banking, 4(1), 117-133.

Khaddafi, M., Falahuddin, Heikal, M., \& Nandari, A. (2017). Analysis Z-score to predict bankruptcy in banks listed in Indonesia stock exchange. International Journal of Economics and Financial Issues, 7(3), 326-330.

Masum, A. A., \& Johora, F. T. (2012). Performance evaluation of selected ceramic companies of Bangladesh. Asian Business Review, 1(1), 37-48. Retrieved fromhttp://oaji.net/articles/2014/800-1398835441.pdf

Mizan, A. N. K., \& Hossain, M. M. (2014). Financial soundness of cement industry of Bangladesh: An empirical investigation using Z-score. American Journal of Trade and Policy, 1(1), 16-22.

Mizan, A. N. K., Amin, M. R., \& Rahman, T. (2011). Bankruptcy prediction by using the Altman Z-score model: An investigation of the pharmaceutical industry in Bangladesh. Bank Parikrama, 36(2-4), 33-56. 
New Age (2019, May 18). Most of MNCs post higher profits in 2018. Retrieved from https://www.newagebd.net/article/72729

Pradhan, R. (December, 2014). Z score estimation for Indian banking sector. International journal of trade, economics and finance, 5(6), 516-520. http://dx.doi.org/10.7763/ IJTEF.2014.V5.425

Ross, S. A., Westerfield, R. W., \& Jordan, B. D. (2002). Fundamentals ofCorporate Finance (6th ed.). New Delhi: Tata McGraw-Hill Publishing Co. Ltd., pp. 586-590.

Sadiq, A. I., Kachollom, P. W., Dasuki, S. I., \& Yusuf, M. (2017). Effect of capital structure on the performance of deposit money banks. International Journal of Accounting \& Finance Review, 1(1), 12-23. https://doi.org/10.46281/ijafr.v1i1.14

Sajjan, R. (April, 2016). Predicting bankruptcy of selected firms by applying Altman's Z-score model. International journal of research-Granthaalayah, 4(4), 152-158.

\section{APPENDICES}

\section{Appendix A: Name of the Firms}

The Names of the Domestic Companies are:

Aftab Automobiles Ltd.(AAL), Agricultural Marketing Company Ltd. (AMCL), Beximco Pharmaceuticals Ltd.(BPL), Square Pharmaceuticals Ltd.(SPL), Apex Footwear Ltd.(AFL), Confidence Cement Ltd.(CCL), and Padma Oil Company Ltd.(POC)

The Names of the MNCs are:

Singer Bangladesh Ltd.(SBD), British American Tobacco Bangladesh Company Ltd.(BATB), GlaxoSmithKline Bangladesh Ltd.(GSK), Reckitt Benckiser (Bangladesh) Ltd.(RBB), Bata Shoe Company Ltd.(BSC), Heidelberg Cement Bangladesh Ltd.(HCL), and Linde Bangladesh Ltd.(LBD)

\section{Appendix B: Acronyms}

MV = Market Value

$\mathrm{TL}=$ Total Liability

$\mathrm{TA}=$ Total Assets

$\mathrm{WC}=$ Working Capital

$\mathrm{BV}=$ Book Value

$\mathrm{TS}=$ Total Sales 


\section{$\mathrm{RE}=$ Retained Earnings \\ $\mathrm{TD}=$ Total Debt}

\section{Copyrights}

Copyright for this article is retained by the author(s), with first publication rights granted to the journal. This is an open-access article distributed under the terms and conditions of the Creative Commons Attribution license (http://creativecommons.org/licenses/by/4.0/) 